\title{
METROPOLITAN, NONMETROPOLITAN, AND SECTIONAL VARIATIONS IN VOTING BEHAVIOR IN RECENT PRESIDENTIAL ELECTIONS
}

\author{
G. TOMAS Murauskas, University of Oklaboma \\ J. CLARK ARCHER, University of Nebraska-Lincoln \\ and \\ FRED M. SHELLEY, University of Southern California
}

HE ADVENT of instantaneous nationwide mass communications,
high levels of interregional mobility, and the concentration of a
majority of Americans in metropolitan centers of seemingly similar character have encouraged a view that sectional forces have diminished in importance as determinants of the geographical outcomes of national elections. More than two decades ago, for example, V. O. Key (1958: 251) asserted that "the sectional foundations of American parties . . have . . . been undergoing a steady erosion. Urbanization can serve as a shorthand term inclusive of a variety of tendencies destructive of sectionalism, such as industrialization, a sharpening of class consciousness, and immigration." Nevertheless, there remains uncertainty as to the relative salience of urbanization versus that of sectionalism in American electoral politics, since these forces have rarely been juxtaposed explicitly in empirical research designs.

The thesis that urbanization has eroded sectionalism embodies a premise that national electoral mosaics - the outcomes of elections viewed geographically in terms of place-to-place differences in levels of support for parties or candidates - have come to exhibit greater variability at smaller urban, suburban and rural scales than at larger sectional scales. To adopt a landscape metaphor, what is implied is that American electoral mosaics have become more aptly describable in terms of smaller ridges and valleys than in terms of larger plains and plateaus. The purpose of the present study is to test this thesis by applying statistical techniques sensitive to spatial variations at different geographical scales to the outcomes of American presidential elections held between 1940 and 1984. Investigation of a time-series of this length is necessary in order to draw comparisons between the patterns of the present and those of the past, when sectional forces are commonly believed to have been stronger. The data analyzed involve the proportions of the total popular vote cast for the Democratic presidential contender during each election from 1940 to 1984 for each county or county equivalent unit in the contiguous United States. Before describing the procedures employed and

Received: December 12, 1986

Revision Received: April 10, 1987

Accepted for Publication: April 14, 1987

Note: We would like to thank Gregory G. Brunk for constructive comments on an earlier draft of the paper. 
the results obtained, however, it is relevant to review briefly literature involving metropolitan-nonmetropolitan and sectional electoral cleavages.

\section{Urban-Suburban-Rural Cleavages: A Review}

Numerous observers of American politics have suggested that national voting sentiments shifted during the New Deal era, "introducing for the first time a significant class cleavage in American politics" (Burnham 1974: 668). As a result of the social and economic tensions of the Great Depression, the electorate as a whole became substantially more Democratic in orientation. Indeed, one contemporary political geographer deemed the 1932 election uninteresting from a geographical perspective, since Roosevelt support predominated over most of the country (Hartshorne 1935).

Explanations of the New Deal transition have varied. Some observers have argued that numerous prior Republican voters switched their party allegiances (Erickson and Tedin 1981), while others have argued that many formerly nonparticipating potential voters with Democratic inclinations became active in considerable numbers (e.g., Key 1966; Burnham 1975; Anderson 1979). Recently, Campbell $(1985,1986)$ argued that conversion and mobilization processes both were involved, with about one-third of the increase in the national Democratic base-line vote between 1928 and 1936 due to shifts in party allegiances, and the remaining two-thirds due to the participation of new voters with Democratic sentiments. Erickson and Tedin (1986) have challenged these estimated proportions, however. But whatever the explanation, the New Deal is often regarded as a period of transition from an earlier epoch of sectionally based politics when divisions between Northerners, Southerners and Westerners had influenced election outcomes to a later epoch of class based politics when divisions between managers, workers, and farmers would influence election outcomes. In Burnham's (1975: 302) phrasing, for example, "The party system became nationalized, although the organizational structures and functions of the major parties themselves remained largely unchanged."

Following World War II, American society exhibited several politically significant trends. One involved an increase in the proportion of the U.S. population living in metropolitan areas, from less than 53 percent in 1940 to nearly 75 percent in 1980 . Antoher entailed the migration of numerous blacks from rural and small town settings in the South to metropolitan settings often in the North and West (Karnig and McClain, 1985 ). By 1980, the proportion of blacks living in metropolitan areas was over 80 percent, with nearly 60 percent in central cities. But while the proportion of whites in metropolitan areas in 1980 was about 73 percent, only 25 percent lived in central cities. Other emergent trends included gravitation of the population as a whole toward the "Sunbelt," encouraging competitive, two-party politics within the once "Solid South." 
Several of these trends already were conspicuous by the 1950s, encouraging analysts to consider their implications regarding elections. The expanding suburbs around major cities attracted particular attention. Often it was assumed that suburbs were homogeneously white, affluent, and middle or upper class in status, seemingly helping to account for Eisenhower's victories in 1952 and 1956. Two major hypotheses were offered to explain suburban Republicanism. These may be referred to as the conversion theory and the transplantation theory. According to the conversion theory, whites moving to the suburbs altered their voting dispositions to minimize partisan tensions with their new neighbors (Wood 1959: 137). One version of the transplantation thesis suggested that many people moving from central cities to suburbs had held long-term Republican preferences beforehand (Campbell, Converse, Miller and Stokes 1964: 280). Another version suggested that partisan conversions occurred in central cities prior to selective migration to suburbs, since a "desire to move to the suburbs is considered part of a larger set of attitudes in which a shift to Republican preference is implicit" (Greenstein and Wolfinger 1959: 474).

Kennedy's victory in 1960 prompted observers to reexamine the "suburban myth." Wirt (1965: 649) found that "In total 49 percent of the suburban vote went for Kennedy" suggesting a need to clarify "the relationship between the suburb as an ecological variable and the elements of suburban organization and culture as class variables." Wirt (1965: 354) observed that suburbs were socially, economically, ethnically and politically more heterogeneous than previously thought, and suggested that "the stereotype of the Republican suburb was built either by examining a few special suburbs, or by equating the Eisenhower successes of the fifties with a permanent Republican growth." The conversion versus transplantation controversy seemed beside the point to Wirt (1965), since suburban Republican successes of the Eisenhower era appeared well within the bounds of national pro-Republican trends. Similarly, Hirsch (1968: 513) argued that "at that time, not only were the suburbs voting strongly Republican, but so were the urban and the rural areas."

Others also challenged the "suburban myth." Examining patterns in the Philadelphia metropolitan area, Williams, Herman, Liebman and Dye (1965) found socially and residentially linked differences in policy preferences. However, the sharpest differences were not between suburbanites and residents of Philadelphia proper, but between residents of higherand lower-ranked suburbs, indicating that inter-suburban cleavages can outweigh city-suburban cleavages. Zikmund (1967) extended these findings to an intermetropolitan scale. Relying upon survey data for the Boston, Chicago, Detroit, Los Angeles, New York, Philadelphia, and San Francisco metropolitan areas, he found that although city-suburban differences with regard to party identification and party loyalty could be detected within metropolitan areas, these differences were greatly overshadowed by inter-metropolitan differences between entire metropolitan complexes. 
Walter and Wirt (1971) examined the five presidential elections between 1948 and 1964 by pooling urban, suburban, and nonmetropolitan counties in 11 non-Southern states to control sectional effects, and then computing average Republican voting proportions for each residential setting. As expected, the lowest average Republican proportion was associated with cities, and the highest average Republican proportion was associated with suburbs. However, when the average proportions were plotted as trend lines it became apparent that "each of the grand divisions responded uniformly to the mixture of short-term forces characteristic of each election. . . . So far from revealing an ever-widening moat between the city and the suburb, our probing uncovers a great similarity between the two in post-World War II America" (Walter and Wirt 1971: 757-58). Later, Wirt (1975: 122) remarked that "looking at the remarkable parallelism of these lines through major decision points in American political history, one can also infer that the locale effect is mitigated or washed out by major secular forces which cause Americans, wherever located, to respond uniformly to them." However, relying upon Zikmund's (1973) evidence of systematic variations from metropolitan area to metropolitan area, Wirt (1975: 129) speculated that "metropolitan, state and national political cultures" might contribute to electoral variations at geographical scales above that of an urban-suburban cleavage.

\section{Sectional Cleavages: A Review}

In part owing to a prevailing notion that class cleavages have grown more salient over time, sectional cleavages have drawn less attention than urban-suburban-rural cleavages in recent research. Earlier, however, sectional voting patterns received emphasis in the work of historian Frederick Jackson Turner, whose contributions to the geography of elections were related to his better known work on the advancing western frontier. "From Bacon's Rebellion to the La Follette revolt," according to Turner (1932: 196), "there are almost continuous manifestations of the sectional contests of East and West, of the frontier and older areas" which rival the more conspicuous divisions between North and South which precipitated the Civil War and persisted through Reconstruction. As the Great Depression descended, however, Turner's attentions to the frontier and to sectional cleavages began to seem atavistic to younger historians more attentive to the presumably class-based tensions of an urban-industrial era. Moreover, Turner's methodology, which involved the laborious mapping of election outcomes at various geographical scales, proved unattractive to later historians (Jensen 1969).

Nevertheless, Turner's careful empirical research inspired several political scientists, including V. O. Key and Daniel Elazar. Key's (1949) monumental Soutbern Politics was liberally illustrated with detailed election maps, and in other works he noted that such maps frequently reveal substantial temporal continuity (e.g., Key and Munger 1959). Examining election trends in Tennessee, for example, Key (1958: 267) found that despite alterations in the issues contested, the "pattern of party division 
within the state remained relatively stable from 1860 to 1948 ." Although the voting acts of particular individuals might seem strange and inexplicable when viewed in isolation, in the aggregate, as Key (1966) emphasized, American voters are about as rational as might be hoped for in a popular democracy embracing a major portion of the North American continent.

Although less concerned with elections than either Turner or Key, Elazar (1984) has identified three sectionally based political cultures which he has labeled "Moralistic," "Traditionalistic," and "Individualistic." In brief, the Moralistic culture involves the collective orientation toward community betterment characteristic of a New England town meeting, the Traditionalistic culture involves a Southern patrician style of politics, and the Individualistic political culture involves a "big-city" conception of political competition including tangible rewards for winning coalitions. While Elazar perhaps has neglected the West as a political entity and doubts may be entertained regarding the contemporary distinctiveness of the Moralistic and Individualistic political culture realms as he has delimited them (Archer and Shelley 1986), his work offers insights into sectional variations in American politics.

Recent studies by electoral geographers have examined sectional voting patterns in the United States. An investigation by Archer and Taylor (1981) employed T-mode factor analysis to group presidential elections conducted between 1832 and 1980 into electoral epochs or normal voting periods using state-level data. One finding was that a single electoral pattern, labeled the Sectional Normal Vote, largely characterized the statelevel pattern of Democratic presidential voting proportions from the 1880 s to the early 1940 s. The same relative geographical patterns of elec-

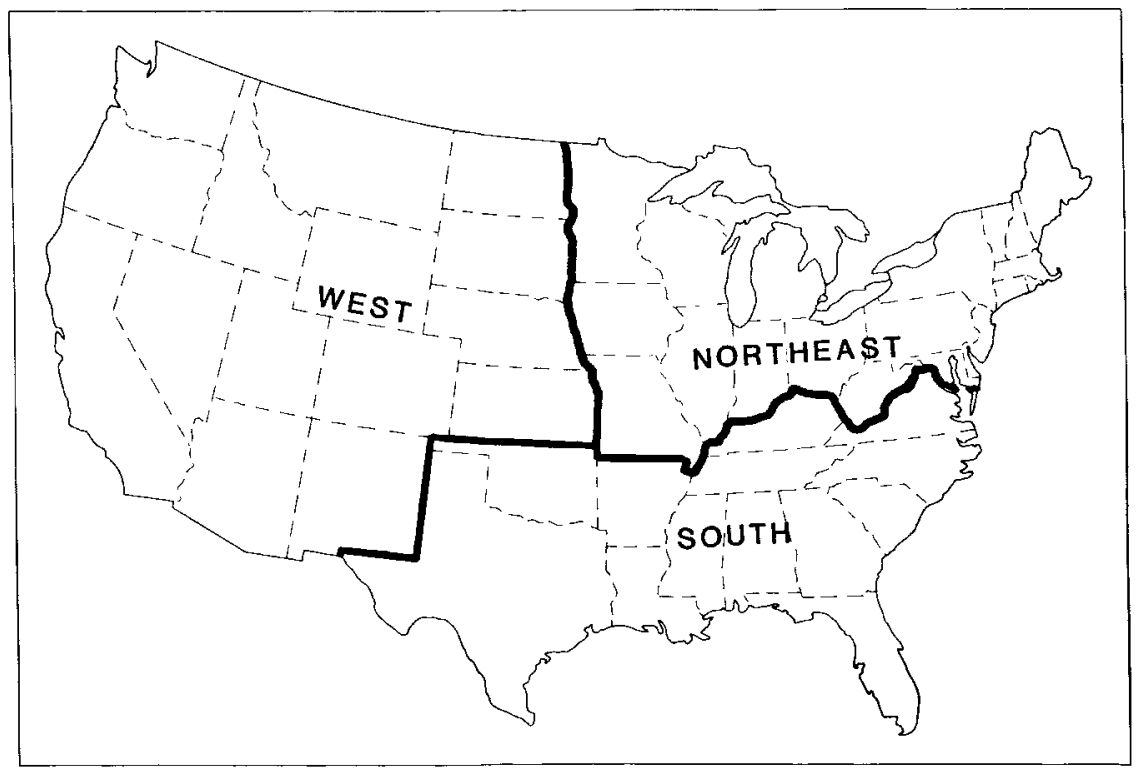


toral support were maintained before and after the onset of the New Deal, albeit at quite different absolute levels of Democratic success. Since the Southern Revolt of 1948, however, state-level normal voting periods have tended to be more short-lived. Archer and Taylor's results show that a Diluted Normal Vote pattern, which manifested itself during the Eisenhower era, was replaced in 1960 by a Liberal Normal Vote pattern extending through the second Nixon election in 1972. This pattern was in turn replaced by a Conservative Normal Vote pattern which appeared in 1976 and persisted through 1980 and 1984 (Archer, Murauskas, Shelley, Taylor and White 1985)

The Archer and Taylor (1981) study also sought to group states into electoral sections through the application of S-mode factor analysis. The inductive results were largely congruent with patterns to be expected from earlier work by Turner (1932). In brief, the results indicate that about 85 percent of the geographical variance associated with election outcomes from 1872 to 1980 over the lower 48 states can be accounted for by grouping states into Northeastern, Southern, and Western electoral sections (Archer and Taylor 1981: 99-113). The remaining 15 percent represents election variance unique to individual states. By and large, these sections consist of sets of geographically contiguous states separated by transition zones which follow the Mason-Dixon Line and the 98th Meridian. Within each section is a core and a periphery, with states in the core exhibiting electoral responses most characteristic of each section as a whole. By way of example, the voting tendencies of Connecticut, Alabama and Idaho, illustrative of trends within the cores of their regions, are more than 80 percent Northern, Southern, and Western, respectively; in contrast, more peripheral Missouri is approximately 35 percent Northern, 20 percent Southern, and 20 percent Western (Archer and Shelley 1986). Time-series regression analyses involving the elections of 1972 , 1976,1980 , and 1984 by Archer $(1982,1985)$ indicate that postdictive models which explicitly recognize sectionally differentiated voting patterns perform significantly better than models which fail to take sectional effects into account at a state level of investigation. A subsidiary objective of the present study is to determine whether the same conclusion is also warranted at a county scale of analysis.

\section{Data AND Methodology}

The primary objective of this research is to examine the popular geographical outcomes of recent presidential elections at county-level for evidence of metropolitan-nonmetropolitan scale and sectional scale electoral cleavages. The sequence of twelve elections from 1940 to 1984 was selected for study partly in light of the results of previous studies of urbansuburban-rural electoral patterns undertaken by political scientists and political sociologists (e.g., Wirt 1965, 1975; Walter and Wirt 1971; Zikmund 1967,1973 ), and partly in light of the results of previous studies of sectional voting patterns undertaken by electoral geographers (e.g., 
Archer and Taylor 1981; Archer, Murauskas, Shelley, Taylor and White 1985).

The study area spans counties and county equivalents within the 48 contiguous states. Alaska and Hawaii were excluded since their residents did not begin to cast votes in presidential elections until midway through the study period. Examples of county equivalents include Louisiana parishes and independent cities such as Baltimore and St. Louis, although several independent cities in Virginia were aggregated with their surrounding counties in order to maintain temporal consistency. County and county equivalents numbered 3070 in 1940 and 1944,3071 in 1948,3072 from 1952 until 1960, and 3073 thereafter. The basic data analyzed consist of the percentage of the total popular vote received by the Democratic party presidential candidate during each election from 1940 to 1984 for each county or county equivalent unit.

It should be noted that counties and county equivalents vary in population and geographical extent. This has strategic electoral as well as statistical implications. Strategically, presidential candidates often target campaign resources toward larger states with higher numbers of electoral votes and within states toward major population centers (Brahms 1978; 'Taylor and Johnston 1979; Bartels 1985; Smith and Squire 1987). Although the paractice of allocating electoral votes on a "winner-take-all" basis by state tends to encourage such targeting, it would be unlikely to disappear under direct election since the average campaign costs of reaching voters are apt to vary inversely with population density and scale. Statistically, if counties and county equivalents were internally homogeneous with respect to all politically salient characteristics as well as equal in population scale and in rates of voter participation, then voting relationships observable at county-level would be apt to parallel voting relationships observable at other levels of spatial aggregation as well (Alker 1969; Johnston 1978). Unfortunately, actual circumstances depart from these conditions so that county-level inferences need not closely mirror individual-level inferences. Despite such caveats, county-level electoral data offer important analytical opportunities, for unlike most available individual-level survey data, county-level election returns provide temporally and spatially exhaustive coverage at a relatively fine-grained geographical scale. Indeed, it may be suggested that perhaps one of the reasons that the relative importance of sectional versus urban-suburbanrural cleavages has been recently neglected is that survey data rarely enable voters to be cross-classified by section as well as by residential setting.

The analysis involves use of ordinary least squares regression (OLS) with county-level Democratic percentages of the total popular vote treated as dependent variables. Each contest is analyzed separately in order to permit quantitative assessment of the relative strengths of metropolitan-nonmetropolitan and sectional cleavages for each election. The mode of analysis is similar to a sequence of analyses of variance except that it additionally yields estimates of the proportions of the total county-level election variance ( $R$-squares) accounted for by a given set of independent variables (Johnston 1978; SAS Institute 1985). 
In order to test for the salience of metropolitan-nonmetropolitan cleavages, counties and county equivalents were categorized as urban, suburban, or rural using U.S. Census metropolitan area delimitations for 1954 and 1981 (U.S. Bureau of Census 1956, 1982). Although the methods employed by the Census to identify and demarcate metropolitan areas are complex - involving issues of population size and density, employment characteristics, and commuting patterns, for example - the general concept "is one of a large population nucleus together with adjacent communities that have a high degree of economic and social integration with that nucleus"' (U.S. Bureau of the Census, 1982: xv). Since the Census of 1950 , this general concept has been operationalized with but minor changes in basic criteria for identifying counties containing central cities of 50,000 or more as metropolitan cores and adjacent counties of metropolitan character as suburban peripheries. However, the adequacy of Census metropolitan area designations as indicators of metropolitannonmetropolitan or of urban-suburban-rural status does vary from one part of the country to another in part because of differences in the sizes and internal homogeneities of counties. Yet alternative delimitations are less attractive, since counties and county equivalents continue to be fundamental reporting units for both Census data and election series. By comparison, such electoral units as wards or precincts generally have little geographical correspondance with such Census units as enumeration districts, tracts, or urbanized areas (Morrill, 1981).

For 1954, 173 Standard Metropolitan Areas (SMAs) were delimited by the Census. One hundred and eight-five counties containing the central cities of these SMAs were coded as urban, another 96 counties within SMA boundaries were coded as suburban, and the remaining counties outside SMA boundaries were coded as rural. This classification of residential settings was used for elections from 1940 to 1964. For 1981, 303 Standard Metropolitan Statistical Areas (SMSAs) were delimited by the Census. Three hundred and forty-five counties containing the central cities of these SMSAs were coded as urban, another 361 counties within SMSA boundaries were coded as suburban, and the remaining counties outside SMSA boundaries were coded as rural. This classification of residential settings was used for elections from 1968 to 1984.

The division of the United States into larger scale sections for purposes of analytical comparison with divisions between urban, suburban and rural residential settings was undertaken in light of earlier electoral research by geographers (Archer and Taylor 1981; Archer, Murauskas, Shelley, Taylor and White 1985; Archer and Shelley 1986; Archer 1982, 1985). Such research has established a firm foundation for expecting that the most likely sectional cleavages under ordinary circumstances are those which differentiate Northeastern, Southern and Western sections along boundaries which correspond with the Mason-Dixon Line and the 98th Meridian (Map 1). The S-mode factor analysis of state-level election results between 1872 and 1980 reported by Archer and Taylor (1981) and discussed above provides perhaps the strongest antecedent evidence for this assertion, since three locationally interpretable factors described over 85 
percent of state-level election variance during this long time span. Too be sure, short-run deviational tendencies reflecting for example subsectional differences between New England and the Mid-Atlantic or the Core and Rim South might well be manifested in the geographical outcome of a given election. However, long-term trends are likely best captured by a tripartite division between Northeast, South and West which fortuitously parallels a tripartite distinction between urban, suburban, and rural residential settings. Although a three-part division in each case can be regarded as placing sectional and metropolitan-nonmetropolitan cleavages on seemingly equal inferential footings, it needs to be acknowledged that the results discussed below are not necessarily generalizable to other conceivable scales and/or lines of spatial partition.

\section{SETTING Versus SECTION}

Between 1940 and 1984 , the nationwide proportion of the total popular vote received by the Democratic candidate varied from slightly less than 40 to slightly more than 60 percent (Table 1 ). The overall average national Democratic proportion is 47.2 percent for the 12 elections combined. Unsurprisingly, county-level mean Democratic voting proportions have tended to rise and fall with changes in national Democratic voting proportions. However, county average proportions have not always matched national proportions due to variations among counties in population size. When candidates do consistently better in less populous counties their county averages will exceed their national proportions; conversely, when candidates do consistently better in more populous counties their national proportions will exceed their county averages.

TABLE 1

Percent Democratic Vote and Variance Explained by Models, Presidential. Elections 1940-1984

\begin{tabular}{|c|c|c|c|c|c|c|}
\hline \multirow[b]{2}{*}{ Election } & \multicolumn{3}{|c|}{ Percent Democratic Vote } & \multicolumn{3}{|c|}{$\begin{array}{c}\text { Percent Variance Explained } \\
\text { (R-Square) }\end{array}$} \\
\hline & $\begin{array}{l}\text { National } \\
\% \text { Dem. }\end{array}$ & $\begin{array}{l}\text { County } \\
\text { Average } \\
\% \text { Dem. }\end{array}$ & $\begin{array}{l}\text { County } \\
\text { St. Dev. } \\
\% \text { Dem. }\end{array}$ & $\begin{array}{c}\text { Model } 1 \\
\text { Settings }\end{array}$ & $\begin{array}{l}\text { Model } 2 \\
\text { Sections }\end{array}$ & $\begin{array}{c}\text { Model } 3 \\
\text { Sections \& } \\
\text { Settings }\end{array}$ \\
\hline 1940 & 54.74 & 60.24 & 20.33 & .25 & 55.33 & 56.11 \\
\hline 1944 & 53.39 & 56.54 & 19.43 & .26 & 48.49 & 49.54 \\
\hline 1948 & 49.55 & 49.62 & 18.28 & .10 & 2.66 & 3.24 \\
\hline 1952 & 44.38 & 44.29 & 16.37 & .03 & 36.34 & 38.25 \\
\hline 1956 & 41.95 & 44.64 & 16.26 & .35 & 22.14 & 23.45 \\
\hline 1960 & 49.72 & 47.30 & 13.59 & .21 & 12.70 & 15.08 \\
\hline 1964 & 61.05 & 55.63 & 14.44 & 1.21 & 7.19 & 8.23 \\
\hline 1968 & 42.72 & 35.20 & 11.50 & 2.39 & 12.92 & 16.08 \\
\hline 1972 & 37.53 & 31.73 & 9.64 & 2.18 & 12.40 & 15.30 \\
\hline 1976 & 50.06 & 51.90 & 11.73 & .75 & 29.83 & 32.57 \\
\hline 1980 & 41.01 & 40.78 & 12.66 & .03 & 39.86 & 42.80 \\
\hline 1984 & 40.56 & 37.02 & 10.57 & 1.66 & 8.46 & 13.51 \\
\hline
\end{tabular}

Source: Computed by authors 
During the early 1940s, for example, county-level Democratic averages were several points ahead of corresponding national figures, reflecting comparative Democratic strength in less populous, rural counties, especially in the South. Since 1960, however, county-level Democratic averages have been below national Democratic proportions except for 1976 , reflecting comparative Democratic strength in more populous, urban counties. These relationships imply that the national Democratic base became more urban centered during the study interval.

Another apparent trend is that the county-level standard deviations of Democratic voting proportions decreased fairly persistently in magnitude from over 20 percent in 1940 to under 10 percent in 1972 . Since 1972 , county scale standard deviations have hovered somewhat above 10 percent. This implies that present total county-to-county electoral variation is about half that of the early 1940s. However, the decline in total national county-to-county electoral variance is not sufficient evidence of dimunition in the saliences of cleavages associated with residential setting or with section, since aggregate variability could have decreased within as well as between these county groupings. Hence, additional evidence needs to be considered.

The proportions of county-scale election variance (R-Squares) accounted for by the variables included in each of the three regression models tested in this research appear in Table 1 . Model 1 posits that county-level electoral variation can be accounted for by distinguishing urban, suburban, and rural residential settings. Model 2 posits that countylevel electoral variation can be accounted for by distinguishing Northern, Southern and Western sections. And Model 3 posits that county-level electoral variation can be accounted for by combining all of these components within a composite formulation.

Model 1 is the weakest of the three models by far. Distinguishing urban, suburban, and rural counties without regard to sectional differences accounts for less than 1 percent of the total county-level election variance for 8 out of the 12 elections. Only for the elections of 1964, 1968, 1972 and 1984 does the proportion of variance explained by differentiating according to residential setting exceed 1 percent; and even for these contests the R-Squares never exceed 2.5 percent. In the absence of other information, knowing whether a county is urban, suburban, or rural reveals unexpectedly little about how it is likely to respond during a presidential election. Although urban counties usually have given Democratic candidates somewhat higher percentages of their popular votes than rural or suburban counties (the contests of 1956 and 1976 are exceptions - Table 2), a great deal of county-level variation remains to be accounted for after noting this surprisingly modest tendency.

Model 2 performs appreciably better than Model 1. On average for the 12 elections, differentiating Northeastern, Southern, and Western sections of the country statistically accounts for about one-quarter of countyscale electoral variation. Moreover, there has not been an entirely persistent decline in the salience of sectional cleavages during the last half century (Table 1). Rather, the salience of sectional distinctions coincid- 
TABLE 2

Modfl I Regression Rescltts: Residfantial Settings

\begin{tabular}{|c|c|c|c|c|}
\hline \multirow[b]{2}{*}{ Election } & \multicolumn{3}{|c|}{ Regression Coefficients } & \multirow[b]{2}{*}{ R-Square } \\
\hline & $\begin{array}{c}\text { Bo } \\
\text { Rural }\end{array}$ & $\begin{array}{c}B 1 \\
\text { Urban }\end{array}$ & $\begin{array}{c}B 2 \\
\text { Suburban }\end{array}$ & \\
\hline 1940 & $\begin{array}{l}60.27 \\
(.000)\end{array}$ & $\begin{array}{l}2.21 \\
(.152)\end{array}$ & $\begin{array}{r}-4.92 \\
(.020)\end{array}$ & $\begin{array}{c}.003 \\
(.020)\end{array}$ \\
\hline 1944 & $\begin{array}{l}56.49 \\
(.000)\end{array}$ & $\begin{array}{l}3.16 \\
(.033)\end{array}$ & $\begin{array}{r}-3.53 \\
(.080)\end{array}$ & $\begin{array}{c}.003 \\
(.018)\end{array}$ \\
\hline 1948 & $\begin{array}{c}49.67 \\
(.000)\end{array}$ & $\begin{array}{l}0.77 \\
(.581)\end{array}$ & $\begin{array}{r}-3.09 \\
(.104)\end{array}$ & $\begin{array}{c}.001 \\
(.219)\end{array}$ \\
\hline 1952 & $\begin{array}{c}44.21 \\
(.000)\end{array}$ & $\begin{array}{l}1.27 \\
(.308)\end{array}$ & $\begin{array}{l}.22 \\
(.895)\end{array}$ & $\begin{array}{l}.000 \\
(.593)\end{array}$ \\
\hline 1956 & $\begin{array}{l}44.94 \\
\quad(.000)\end{array}$ & $\begin{array}{c}-2.90 \\
\quad .019)\end{array}$ & $\begin{array}{c}-4.08 \\
(.016)\end{array}$ & $\begin{array}{l}.004 \\
(.004)\end{array}$ \\
\hline 1960 & $\begin{array}{l}47.10 \\
(.000)\end{array}$ & $\begin{array}{l}2.41 \\
(.020)\end{array}$ & $\begin{array}{l}1.57 \\
(.265)\end{array}$ & $\begin{array}{c}.002 \\
(.040)\end{array}$ \\
\hline 1964 & $\begin{array}{l}55.13 \\
(.000)\end{array}$ & $\begin{array}{l}5.85 \\
(.000)\end{array}$ & $\begin{array}{l}4.76 \\
(.001)\end{array}$ & $\begin{array}{c}.012 \\
(.000)\end{array}$ \\
\hline 1968 & $\begin{array}{c}34.63 \\
(.000)\end{array}$ & $\begin{array}{l}5.56 \\
(.000)\end{array}$ & $\begin{array}{l}-.44 \\
(.492)\end{array}$ & $\begin{array}{c}.024 \\
(.000)\end{array}$ \\
\hline 1972 & $\begin{array}{l}31.43 \\
\quad(.000)\end{array}$ & $\begin{array}{l}4.11 \\
(.000)\end{array}$ & $\begin{array}{r}-1.36 \\
(.012)\end{array}$ & $\begin{array}{c}.022 \\
(.000)\end{array}$ \\
\hline 1976 & $\begin{array}{c}52.44 \\
\quad(.000)\end{array}$ & $\begin{array}{c}-2.93 \\
(.000)\end{array}$ & $\begin{array}{c}-1.73 \\
(.009)\end{array}$ & $\begin{array}{c}.008 \\
(.000)\end{array}$ \\
\hline 1980 & $\begin{array}{c}40.84 \\
\quad(.000)\end{array}$ & $\begin{array}{l}.11 \\
(.878)\end{array}$ & $\begin{array}{l}-.63 \\
(.377)\end{array}$ & $\begin{array}{c}.000 \\
(.652)\end{array}$ \\
\hline 1984 & $\begin{array}{c}36.90 \\
\quad(.000)\end{array}$ & $\begin{array}{l}3.38 \\
(.000)\end{array}$ & $\begin{array}{c}-2.23 \\
(.000)\end{array}$ & $\begin{array}{c}.017 \\
(.000)\end{array}$ \\
\hline
\end{tabular}

Levels of statistical significance shown in parentheses; values of .050 or less indicate significance at .05 , values of .010 or less indicate significance at .01 , etc.

Source: Computed by authors.

ing with the Mason-Dixon Line and the 98th Meridian has varied considerably since the eve of World War II. On three occasions, in 1948, 1964 and 1984, sectional divisions along these boundaries accounted for less than 10 percent of total county-level election variation. In two of these instances, however - involving Thurmond's States' Rights Democratic candidacy in 1948 and Goldwater's Republican candidacy in 1964 - the modest importance of overall North-South-West cleavages can be attributed partly to divisions which manifested themselves at a sub-sectional scale, with the Core South exhibiting a response at odds with that of the Rim South (Shelley and Archer 1985).

Since 1940, the proportion of county-level variation in Democratic voting percentages attributable to intersectional differences aligned with the Mason-Dixon Line and the 98th Meridian has exceeded one-third in $1940,1944,1952$, and 1980, and was close to this level in 1976 as well. While sectional divisions along these boundaries were more intense during the late Roosevelt era, it is also apparent that sectional cleavages of 
considerable strength have reappeared on several occasions since then. Thus, with notable exceptions such as those of 1948 or 1964, it is apparent that the overall decrease in total county-to-county electoral variation which has taken place during the past half century generally has been more a product of diminished intrasectional variation than of diminished intersectional variation. As recently as 1976 and 1980, as much as onethird of total county-level electoral variance can be attributed to differences between sections.

\section{SETTING AND SECTION}

The conclusions drawn so far can be extended by examining graphical representations of the results for Models 1 and 2, and by considering the results for composite Model 3 more closely. Figure 1 shows the average proportions of the vote received by Democratic presidential candidates in urban, suburban, and rural counties over time. These averages derive from regression results for Model 1 in the following mannner. The intercept (BO) values for Model 1 identify average Democratic vote proportions for rural counties at each election (Table 2). The slope (B1 and B2) values show by how much the averages for urban and suburban counties differed from the average for rural counties at each election. So, for example, the average urban percentage for 1940 was 60.27 (B0) plus 2.21 (B1), or 62.48 percent, and the average suburban percentage

FIGURE 1

Average Percent Democratic by Residential Setting, 1940-1984

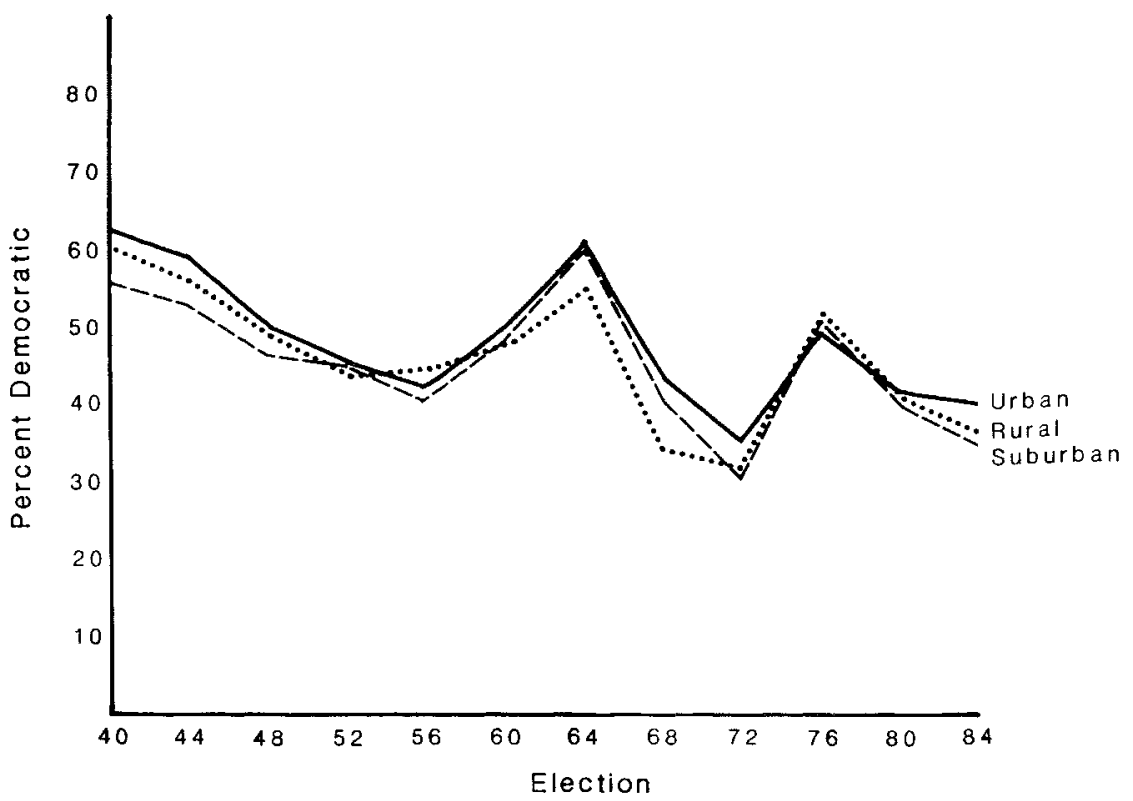


for the same election was 60.27 (B0) minus 4.92 (B2), or 55.35 percent. Similar computaions yield the graphed values for other combinations of elections and models.

As Walter and Wirt (1971) and Wirt (1975) found earlier using Republican voting proportions, a shorter time interval (1948-1964), and a sample of but 11 states, the tendency has been for voting splits in urban, suburban, and rural residential settings to change over time in close unison, suggesting an absence of sharp electoral cleavages between these settings. Although these settings generally differ by several percentage points for each election, the overall differences from election to election tend to be considerably more conspicuous, at least when regional variations are disregarded as with most earlier research and the evidence presented in Figure 1. Rarely during the past 12 elections have the differences separating rural, urban, and suburban county averages exceeded 6 percentage points, and the average difference has been but 4.3 percentage points between these county groupings.

The graph (Figure 2) portraying sectional averages (Table 3) over time reveals that there has usually been much more distinctiveness between sections. Indeed, the average sectional difference between county average election proportions has been 15.2 percentage points over the 12 elections under study, or more than three times the average difference between residential settings. However, while the differences among sections were less than 8 percent in 1948, 1972 and 1984, they were more

FIGURE 2

Average Percent Democratic by Section, 1940-1984

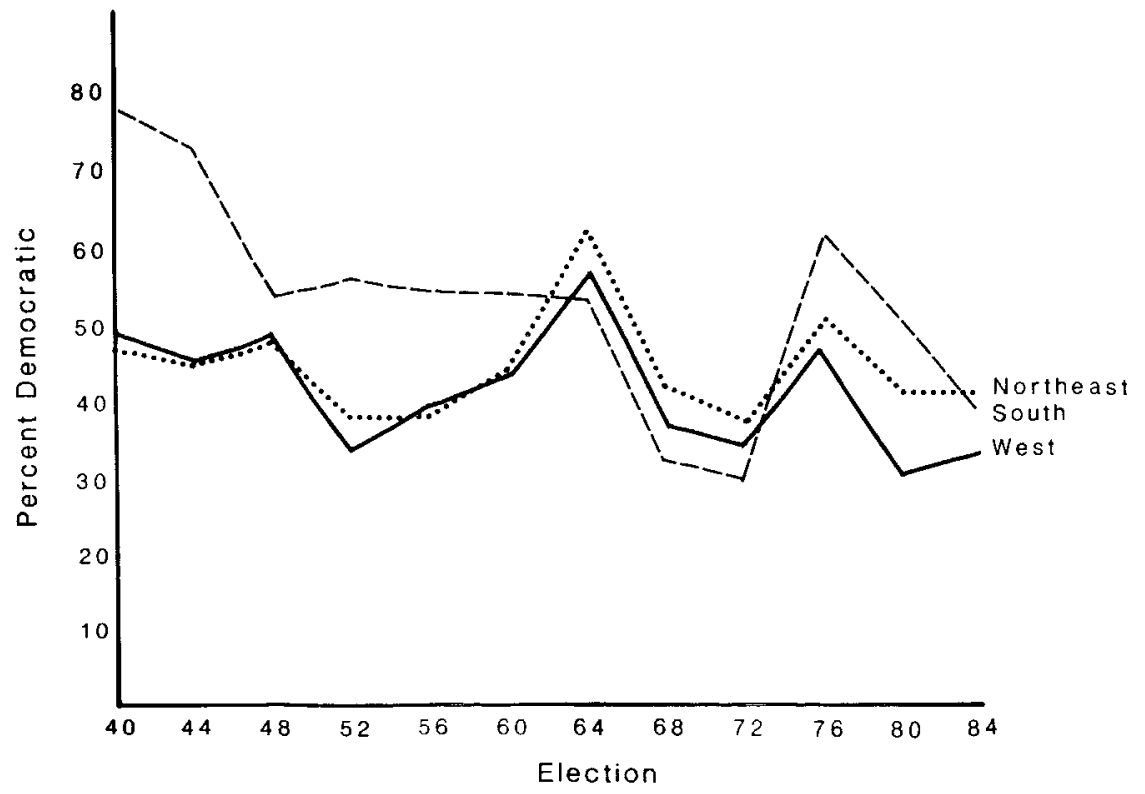


TABLE 3

MODEl II Regression ResUlts: Sections

\begin{tabular}{|c|c|c|c|c|}
\hline \multirow[b]{2}{*}{ Election } & \multicolumn{3}{|c|}{ Regression Coefficients } & \multirow[b]{2}{*}{$R$-Square } \\
\hline & $\begin{array}{c}\text { Bo } \\
\text { North }\end{array}$ & $\begin{array}{c}\text { B1 } \\
\text { South }\end{array}$ & $\begin{array}{c}B 2 \\
\text { West }\end{array}$ & \\
\hline 1940 & $\begin{array}{l}46.41 \\
(.000)\end{array}$ & $\begin{array}{c}31.38 \\
(.000)\end{array}$ & $\begin{array}{l}2.04 \\
(.002)\end{array}$ & $\begin{array}{l}.553 \\
(.000)\end{array}$ \\
\hline 1944 & $\begin{array}{l}44.44 \\
(.000)\end{array}$ & $\begin{array}{l}27.80 \\
\quad(.000)\end{array}$ & $\begin{array}{l}1.08 \\
(.108)\end{array}$ & $\begin{array}{l}.485 \\
(.000)\end{array}$ \\
\hline 1948 & $\begin{array}{l}46.72 \\
(.000)\end{array}$ & $\begin{array}{l}6.34 \\
(.000)\end{array}$ & $\begin{array}{l}.83 \\
(.340)\end{array}$ & $\begin{array}{l}.027 \\
(.000)\end{array}$ \\
\hline 1952 & $\begin{array}{l}37.75 \\
(.000)\end{array}$ & $\begin{array}{c}17.84 \\
(.000)\end{array}$ & $\begin{array}{l}-4.43 \\
(.000)\end{array}$ & $\begin{array}{l}.363 \\
(.000)\end{array}$ \\
\hline 1956 & $\begin{array}{c}37.84 \\
(.000)\end{array}$ & $\begin{array}{c}15.68 \\
(.000)\end{array}$ & $\begin{array}{l}.54 \\
(.440)\end{array}$ & $\begin{array}{l}.221 \\
(.000)\end{array}$ \\
\hline 1960 & $\begin{array}{l}43.25 \\
(.000)\end{array}$ & $\begin{array}{l}9.68 \\
(.000)\end{array}$ & $\begin{array}{l}-.28 \\
(.648)\end{array}$ & $\begin{array}{l}.127 \\
(.000)\end{array}$ \\
\hline 1964 & $\begin{array}{l}60.69 \\
(.000)\end{array}$ & $\begin{array}{r}-8.92 \\
(.000)\end{array}$ & $\begin{array}{c}-5.32 \\
(.000)\end{array}$ & $\begin{array}{c}.072 \\
(.000)\end{array}$ \\
\hline 1968 & $\begin{array}{l}40.42 \\
(.000)\end{array}$ & $\begin{array}{r}-9.52 \\
(.000)\end{array}$ & $\begin{array}{c}-4.91 \\
\quad(.000)\end{array}$ & $\begin{array}{l}.129 \\
(.000)\end{array}$ \\
\hline 1972 & $\begin{array}{l}35.89 \\
(.000)\end{array}$ & $\begin{array}{c}-7.79 \\
(.000)\end{array}$ & $\begin{array}{r}-3.58 \\
(.000)\end{array}$ & $\begin{array}{c}.120 \\
(.000)\end{array}$ \\
\hline 1976 & $\begin{array}{c}48.38 \\
(.000)\end{array}$ & $\begin{array}{c}10.72 \\
(.000)\end{array}$ & $\begin{array}{c}-4.37 \\
(.000)\end{array}$ & $\begin{array}{c}.298 \\
(.000)\end{array}$ \\
\hline 1980 & $\begin{array}{l}39.12 \\
\quad(.000)\end{array}$ & $\begin{array}{l}9.77 \\
(.000)\end{array}$ & $\begin{array}{r}-10.48 \\
(.000)\end{array}$ & $\begin{array}{c}.399 \\
(.000)\end{array}$ \\
\hline 1984 & $\begin{array}{l}38.89 \\
(.000)\end{array}$ & $\begin{array}{l}-.29 \\
(.486)\end{array}$ & $\begin{array}{l}-7.38 \\
\quad(.000)\end{array}$ & $\begin{array}{c}.085 \\
(.000)\end{array}$ \\
\hline
\end{tabular}

Levels of statistical significance shown in parentheses; values of .050 or less indicate significance at .05 , values of .010 or less indicate significance at .01 , etc.

Source: Computed by authors.

than 20 percent in $1940,1944,1952$ and 1980 . Thus, sectional distinctions have varied rather substantially in their electoral importance during the past half century.

It is also relevant to observe that relative levels of Democratic support by section have shifted rather strikingly during the study period. From 1940 to 1960 the South gave considerably greater popular support to Democratic candidates than either the North or West, and the Northern and Western averages tended to vary in unison over time. Beginning in 1964, however, the relative regional rankings became more volatile. Between 1964 and 1972 counties in the South yielded the lowest average Democratic proportions, while those in the North yielded the highest. A Southerner at the head of the Democratic ticket in 1976 prompted nearly a 30 point jump in the Southern average by comparison with 1972 . Since 1976 the West has consistently been the least Democratic section of the nation in terms of county-scale averages. 
Distinguishing counties in terms of whether they are located in the Northeastern, Southern, or Western portions of the nation clearly is more electorally important than distinguishing them in terms of urban, suburban, or rural character. But what if these two categorizations are combined? Model 3, which differentiates counties within each section in terms of whether they are urban, suburban, or rural, generally provides a marginal gain over Model 2 in terms of total county-to-county variance explained (Table 4). For all 12 elections, the proportion of county-scale variance accounted for by Model 3 averages slightly more than 26 percent for the composite model. While this is not a spectacular improvement over Model 2, most Model 3 coefficients are statistically significant for each election, indicating that differentiating both section and residential setting simultaneously is a warranted analytical exercise.

Since Model 3 involves a rather large number of individual coefficients, the regression results are once again depicted graphically to facilitate discussion (Figure 3). Each subgraph displays county-scale averages for urban, suburban, and rural counties within a given section. As expected, the urban, suburban, and rural trends within each region are similar to one another. If urban, suburban and rural trends are compared between sections, however, identifiable contrasts appear. For example, Southern urban voting trends parallel Southern suburban and rural trends more closely than they do Northeastern or Western urban trends.

Urban counties generally have led rural and suburban counties in terms of their average Democratic percentages in the North and West. The same has not been true in the South. Urban, rural, and suburban counties returned nearly identical Democratic averages in the South during the Roosevelt elections examined. But rural Southern counties exhibited higher Democratic averages than urban or suburban Southern counties in 8 out of the last 10 elections; moreover, Southern suburban counties exhibited higher Democratic averages than Southern urban counties in 5 out of the last 10 elections. This ordering sharply contrasts with patterns found elsewhere and reflects changes in the Southern electorate since the 1940s. Before the Voting Rights Act of 1965 and other reforms, the electoral participation rate of Southern blacks, many of whom live in rural or small town settings, was quite low. The subsequent increase in black electoral particiation has tended to benefit Democratic candidates in the nonmetropolitan South especially. In 1984, for example, whereas barely one-quarter of Southern whites supported the national Democratic ticket, more than nine-tenths of Southern blacks did so; indeed, "in the South, more than half of Mondal's vote came from blacks" (Schneider 1984: 2132). By comparison, "the Republican party's successes in Southern elections at the presidential level of competition have been fostered in the more urban places, " with more populous Southern counties typically being more Republican in orientation (Ingalls and Brunn 1979: 84). This example clearly illustrates that electoral stereotypes based upon national voting patterns do not necessarily apply within sections.

In the Northeast, where "suburban Republicanism" was perhaps first noted, the average suburban proportion of the popular vote received by 
FIGURE 3

Average Percent Democratic by Section and Residential Setting 1940-1984
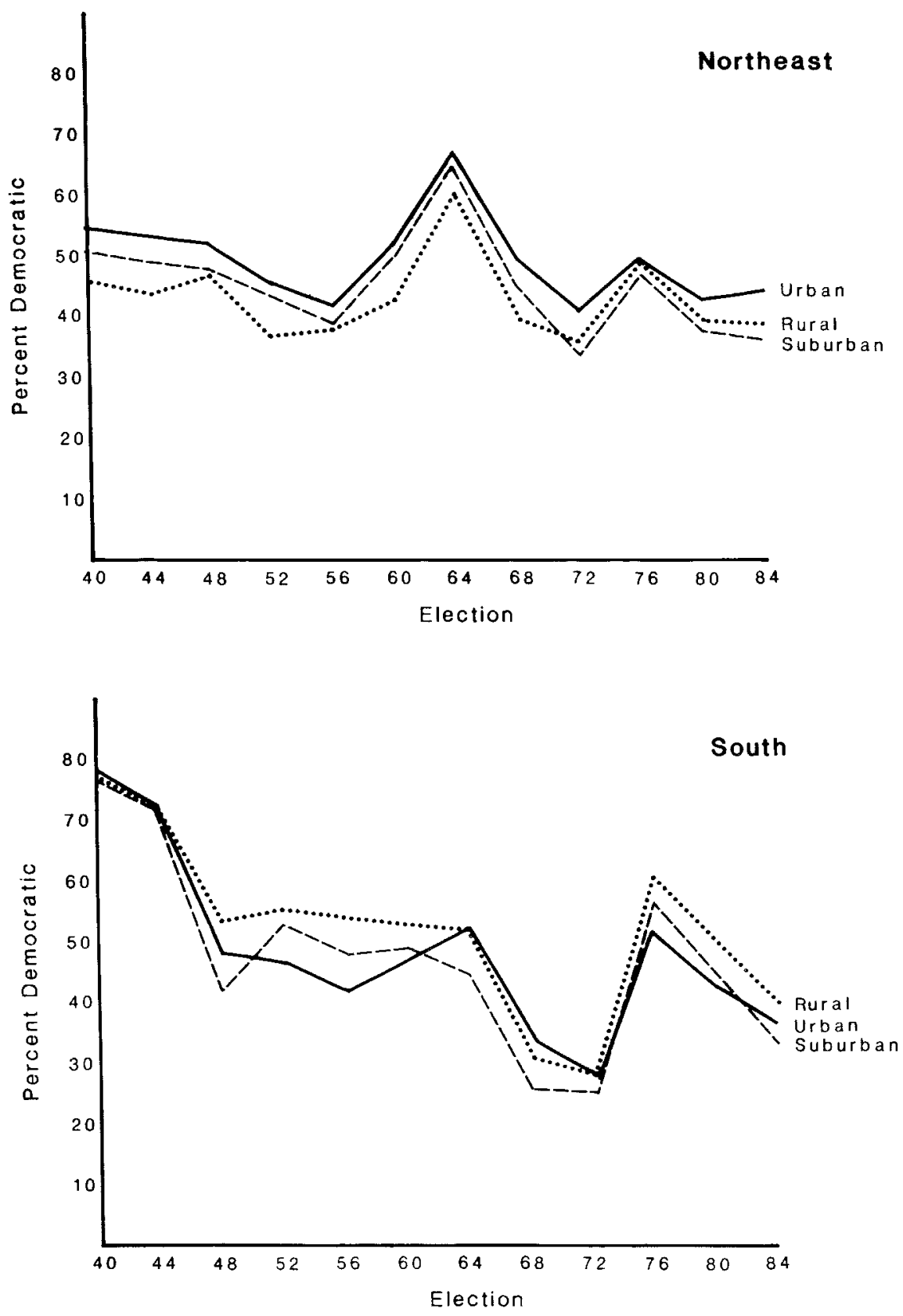
Figure 3. (Continued)

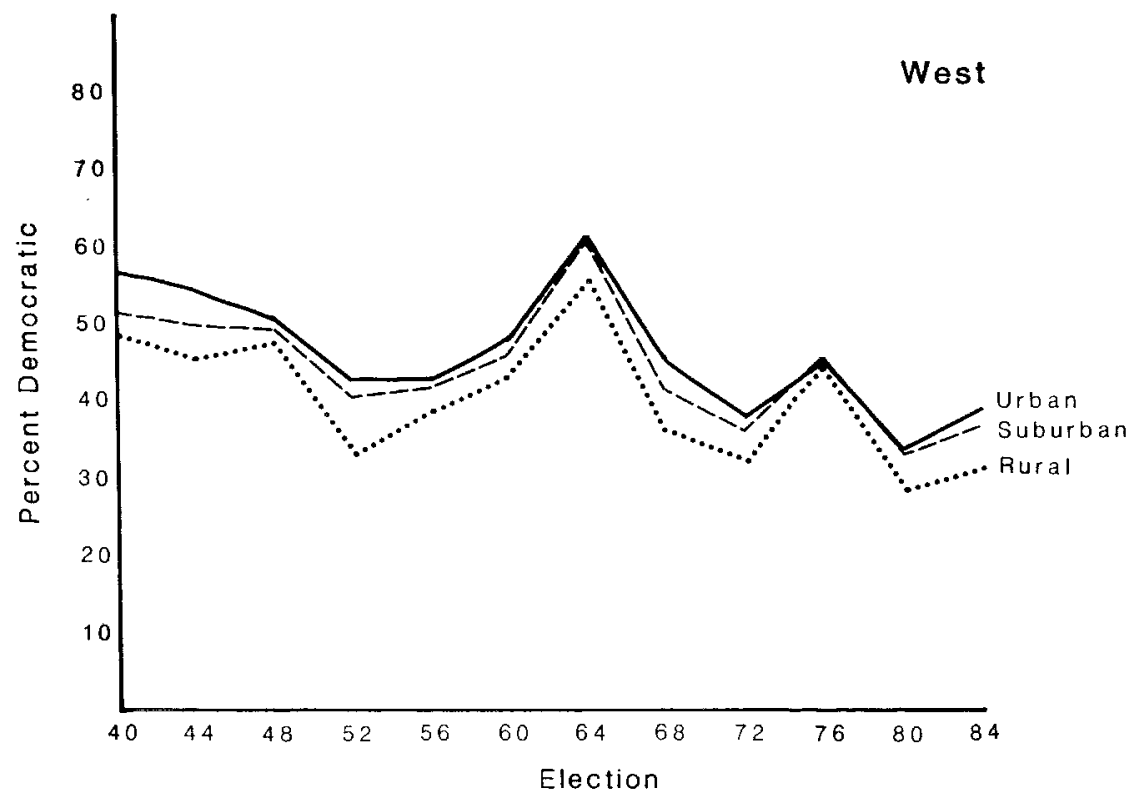

Democratic candidates fell behind the average rural proportion only from 1972 onwards. Until then, rural Northeastern counties were relatively more Republican than their suburban counterparts. Since approximately 1968 , the cleavage separating urban and suburban counties in the Northeast generally has widened, with the difference exceeding 8 percentage points during the 1984 election.

In the West, in contrast, urban and suburban averages have generally moved in close concert with one another throughout the period of study. This partly reflects a tendency for Western urban and suburban residential settings to be less distinctive in social and economic respects than is the case to the east of the 98th Meridian where metropolitan areas are more sharply nucleated than is the case in the West. Nevertheless, the growing electoral cleavage between urban and suburban counties apparent in the Northeast is much less apparent in the West, where a cleavage between metropolitan and nonmetropolitan counties is the more noticeable. In the West, a division between metropolitan counties and nonmetropolitan counties was especially pronounced for the elections won by Eisenhower, Nixon, and Reagan. During these contests, the Democratic proportion of the popular vote averaged but 32.6 percent among Western rural counties, or about 6 percentage points below Western urban and suburban counties combined. 


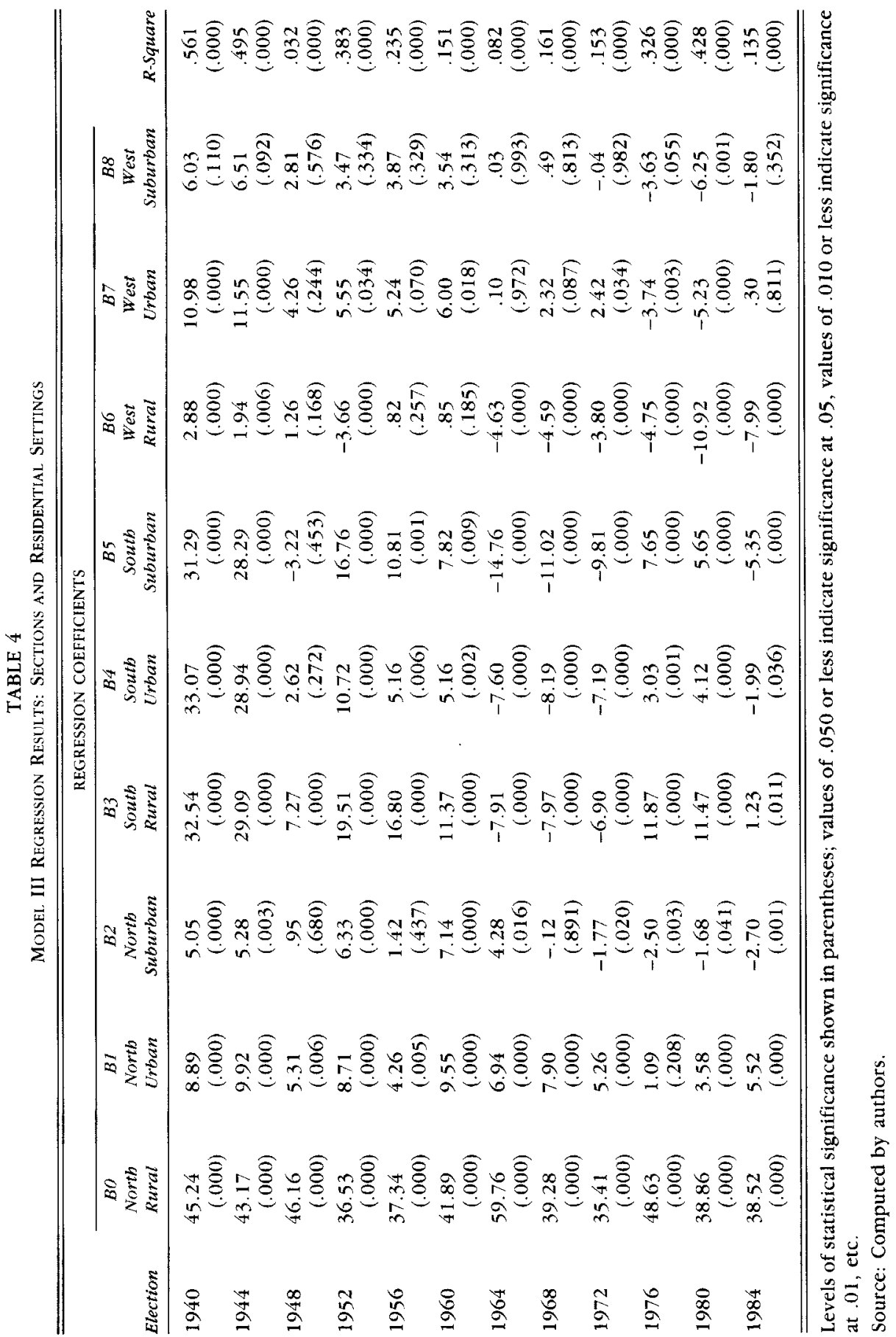




\section{Summary AND CONCLUSIONS}

According to conceptual formulations based upon inferences from the general evolution of American society, and particularly the transformation of American society from the rural-industrial base of an earlier period to the metropolitan-service base of the so-called "post-industrial" era, it might be expected that sectional cleavages have been supplanted by metropolitan- nonmetropolitan cleavages. However, the statistical results of the present study do not imply that metropolitan-nonmetropolitan cleavages have replaced sectional cleavages in the county-level outcomes of American presidential elections. Briefly, the findings may be summarized as follows:

First, standard deviations computed for Democratic voting percentages over all counties nationally decreased from the 1940 s to the early 1970 s. Since then, county-level standard deviations have remained close to a value of 10 percent. Hence, there generally is less geographical variation in voters' responses to major party presidential candidates at present than there was several decades ago.

Second, urban, suburban, and rural responses to major party presidential candidates have tended to vary similarly over time. In none of the elections examined was a national distinction between urban, suburban, and rural residential settings found to account for more than two and one-half percent of total county-level election variance. Hence, disregarding sectional divisions, cleavages between urban, suburban, and rural residential settings have been substantially less conspicuous than conventional wisdom suggests.

Third, sectional cleavages exerted a varying - though sometimes substantial - impact upon the results of American presidential elections between 1940 and 1984. On average for the 12 elections studied, a distinction between Northeastern, Southern, and Western sections of the nation accounted for about 24 percent of the total county-level variance in Democratic presidential voting proportions. This distinction accounted for one-third of the variance as recently as 1976 and 1980. Hence, the overall decline in county-level election variance since 1940 has scarcely diminished sectional cleavages to the vanishing point.

Fourth, urban-suburban-rural distinctions vary in electoral consequences between sections. For example, while urban counties have generally been more supportive of Democratic presidential candidates than rural or suburban counties in the Northeast and West, stronger Democratic support has become more of a rural phenomenon in the South. Hence, the electoral implications of "urban-ness," "suburban-ness," and "ruralness" differ by section.

In conclusion, the present findings lend scant support to a view that urban, suburban, and rural divisions have come to overshadow Northeastern, Southern, and Western divisions in American electoral politics. To paraphrase Mark Twain's reaction upon encountering his own obituary: The reports of the demise of sectionalism are greatly exaggerated. 


\section{REFERENCES}

Alker, Hayward R. 1969. “A Typology of Ecological Fallacies." In Matti Dogan and Stein Rokkan, eds., Quantitative Ecological Analysis in the Social Sciences. Cambridge, MA: MIT Press.

Anderson, Kristi. 1979. "Generation, Partisan Shift, and Realignment: A Glance Back to the New Deal." in Norman H. Nie, Sidney Verba, and John R. Petrocik, The Changing American Voter, enlarged ed. Cambridge, MA: Harvard University Press.

Archer, J. Clark. 1982. "Some Geographical Aspects of the American Presidential Election of 1980." Political Geography Quarterly 1: 123-35.

1985. "Some Geographical Aspects of the American Presidential Election of 1984." Political Geography Quarterly 4: 159-72.

, G. Tomas Murauskas, Fred M. Shelley, Peter J. Taylor, and Ellen R. White. 1985. "Counties, States, Sections, and Parties in the 1984 Presidential Election." Professional Geographer 37: 279-87.

and Fred M. Shelley. 1986. American Electoral Mosaics. Washington,

D.C.: Association of American Geographers. and Peter J. Taylor. 1981. Section and Party. New York: Wiley.

Bartels, Larry M. 1985. "Resource Allocation in a Presidential Campaign." Journal of Politics 47: 928-36.

Brams, Steven J. 1978. The Presidential Election Game. New Haven: Yale University Press.

Burnham, Walter Dean. 1974. "The United States: the Politics of Heterogeneity." In R. Rose, ed., Electoral Behaviour. New York: Free Press.

1975. "Party Systems and the Political Process." In William Nisbet Chambers and Walter Dean Burnham, eds., The American Party Systems, 2nd. ed. New York: Oxford.

Campbell, Angus, Phillip E. Converse, Warren E. Miller, and Donald E. Stokes. 1964. The American Voter: An Abridgement. New York: Wiley.

Campbell, James E. 1985. "Sources of the New Deal Realignment: The Contributions of Conversion and Mobilization to Partisan Change." Western Political Quarterly 38: 357-76.

1986. "Voter Mobilization and the New Deal Realignment: A Rejoinder to Erickson and Tedin." Western Political Quarterly 39: 733-35.

Elazar, Daniel J. 1984. American Federalism: A View from the States, 3rd. ed. New York: Harper and Row.

Erickson, Robert S., and Kent L. Tedin. 1981. "The 1928-1936 Partisan Realignment: The Case for the Conversion Hypothesis." American Political Science Review 75: 951-62.

1986. "Voter Conversion and the New Deal Realignment: A Response to Campbell." Western Political Quarterly 39: 729-32.

Greenstein, Fred I., and Raymond E. Wolfinger. 1958-59. "The Suburbs and Shifting Party Loyalties." Public Opinion Quarterly 22: (Winter): 473-82.

Hartshorne, Richard. 1935. "Recent Developments in Political Geography II." American Political Science Review 29: 943-66.

Hirsch, Herbert. 1968. "Suburban Voting and National Trends: A Research Note." Western Political Quarterly 21: 508-14. 
Ingalls, Gerald L., and Stanley D. Brunn. 1979. "Electoral Change in the American South, 1948-1976: The Influence of Population Size." Soutbeastern Geographer 29: 80-90.

Jensen, R. 1969. "American Election Analysis: A Case History of Methodological Innovation and Diffusion." In Seymour Martin Lipset, ed., Politics and the Political Scientist. New York: Oxford University Press.

Johnston, Ronald J. 1978. Multivariate Statistical Analysis in Geograpby. London: Oxford University Press.

Karnig, Albert K., and Paula D. McClain. 1985. "The New South and Black Economic and Political Development: Changes from 1970 to 1980." Western Political Quarterly 38: 539-50.

Key, V. O. 1949. Southern Politics in State and Nation. New York: Knopf. 1958. Politics, Parties, and Pressure Groups, 4 th ed. New York: Crowell. 1966. The Responsible Electorate: Rationality in Presidential Voting 1936-1960. Cambridge, MA: Belknap.

, and Frank Munger. 1959. "Social Determinism and Electoral Decision: The Case of Indiana." In Eugene Burdick and Arthur J. Brodbeck, eds., American Voting Bebavior, pp. 281-99. Glencoe: Free Press.

Morrill, Richard L. 1981. Political Redistricting and Geographic Theory. Washington, D.C.: Association of American Geographers.

SAS Institute. 1985. SAS User's Guide: Statistics, Version 5 Ed. Cary, North Carolina: SAS Institute.

Schneider, Wiliam. 1984. "An Uncertain Consensus." National Journal 16: 2130-32.

Shelley, Fred M., and J. Clark Archer. 1985. "Post-War Presidential Elections in the Sunbelt." Presented to "The Sunbelt: A Region and Regionalism in the Making." Miami, Florida, November 5.

Smith, Eric R. A. N., and Peverill Squire. 1987. "Direct Election of the President and the Power of the States." Western Political Quarterly 40: 29-44.

Tatalovich, Raymond. 1979. "Electoral Votes and Presidential Campaign Trails." American Politics Quarterly 7: 489-97.

Taylor, Peter J., and Ronald J. Johnston. 1979. Geography of Elections. Harmondsworth, England: Penguin.

Turner, Frederick Jackson. 1932. The Significance of Sections in American History. New York: Holt.

U.S. Bureau of the Census. 1956. County and City Data Book. Washington, D.C.: U.S. Government Printing Office.

1982. State and Metropolitan Area Date Book. Washington, D.C.: U.S. Government Printing Office.

Walter, Benjamin, and Frederick M. Wirt. 1971. "The Political Consequences of Suburban Variety." Social Science Quarterly 2: 746-67.

Williams, Oliver P., Herold Herman, Charles S. Liebman, and Thomas R. Dye. 1965. Suburban Differences and Metropolitan Policies: A Pbiladelpbia Story. Philadelphia: University of Pennsylvania Press.

Wirt, Frederick. 1965. "The Political Sociology of American Suburbia: A Reinterpretation." Journal of Politics 27: 647-66.

1975. "Suburbs and Politics in America." Publius 5: 121-44. 


\section{Western Political Quarterly}

Wood, Robert C. 1959. Suburbia: Its People and their Politics. Boston: Houghton Mifflin.

Zikmund, Joseph. 1967. "A Comparison of Political Attitude and Activity Patterns in Central Cities and Suburbs." Public Opinion Quarterly 31: 69-75.

1973. "Suburbs in State and National Politics." In Louis H. Masotti and Jeffrey K. Hadden, eds., The Urbanization of the Suburbs, Urban Affairs Annual Review. Vol. 7. Beverly Hills: Sage. 